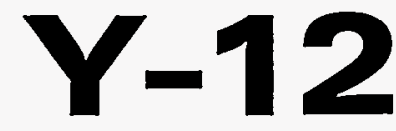

OAK RIDGE

$\mathrm{Y}-12$

PLANT

LOC K HEED M A

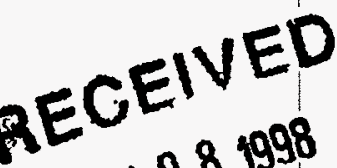

JUN 081998

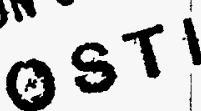

(B)

Project Accomplishment Summary

for

Project Number 94-MULT-003-D2-04

\section{ELECTRON BEAM CURING OF POLYMER MATRIX} COMPOSITES

Christopher J. Janke

Lockheed Martin Energy Systems, Inc.

Dave Wheeler

Sandia National Laboratory

Chris Saunders

AECL Technologies, Inc.

Rich Moulton

Applied Poleramic, Inc.

Terry Tsuchiyama

Boeing Commercial Airplane Group

Yafim Blaykman

Ciba-Geigy Corporation

Tom Knobel

E-Beam Services, Inc. Ben Clark

Lockheed Martin Tactical Aircraft Systems Alla Oliger

Lockeed Martin Aero \& Navel Systems Lewis Parks

Nicolet Electron Services Anna Yen

Northrop Grumman, B-2 Division

Morris Johnson

UCB Chemical Corporation

January 8, 1998

Approved for Public Release;

distribution is unlimited.

Prepared by the

Oak Ridge Y-12 Plant

managed by

LOCKHEED MARTIN ENERGY SYSTEMS, INC.

for the

U.S. DEPARTMENT OF ENERGY

under contract DE-AC05-840R21400

MASTER

LOCKHEED MARTIN ENERGY SYSTEMS, INC.

FOR THE UNITED STATES

DEPARTMENT OF ENERGY

UCN-13672 (28 6-85)
DISTAIBUTION OF THIS DOCUMENT IS UNLMITEO 


\section{DISCLAIMER}

This report was prepared as an account of work sponsored by an agency of the United States Government. Neither the United States Government nor any agency thereof, nor any of their employees, makes any warranty, express or implied, or assumes any legal liability or responsibility for the accuracy, completeness, or usefulness of any information, apparatus, product, or process disclosed, or represents that its use would not infringe privately owned rights. Reference herein to any specific commercial product, process, or service by trade name, trademark, manufacturer, or otherwise, does not necessarily constitute or imply its endorsement, recommendation, or favoring by the United States Government or any agency thereof. The views and opinions of authors expressed herein do not necessarily state or reflect those of the United States Government or any agency thereof. 


\section{DISCLAIMER}

Portions of this document may be illegible electronic image products. Images are produced from the best available original document. 


\section{PROJECT ACCOMPLISHMENT SUMMARY}

Title: $\quad$ Electron Beam Curing Of Polymer Matrix Composites

DOE TTI Number: 94-MULT-003-D2-04

CRADA Number: Y1293-0233

Partners: $\quad$ Lockheed Martin Energy Systems; Sandia National Laboratory; AECL Technologies, Inc.; Applied Poleramic, Inc.; Boeing Commercial Airplane Group; Ciba-Geigy Corporation; E-Beam Services, Inc.; Lockheed Martin Tactical Aircraft Systems; Lockheed Martin Aero \& Naval Systems; Nicolet Electron Services; Northrop Grumman, B-2 Division; UCB Chemicals Corporation.

\section{BACKGROUND}

A major cost driver in manufacturing Polymer Matrix Composites (PMC) parts and structures, and one of the elements having the greatest effect on their quality and performance, is the conventional thermal cure process. Thermal curing of PMCs requires long cure times and high energy consumption, creates residual thermal stresses in the part, produces volatile toxic byproducts, and requires expensive tooling that is tolerant of the high cure temperatures used in the manufacture of PMCs. Many of the shortcomings of thermal curing methods can be reduced or eliminated by using electron beam curing.

Electron beam curing of PMCs is a rapid, low-cost, non-thermal, non-autoclave curing process that enhances specific physical, mechanical and chemical properties. This curing method uses high-energy electrons and/or X-rays as ionizing radiation to initiate polymerization and crosslinking reactions at controlled rates in electron beam curable materials. This technology represents an enabling capability for both economical manufacturing of PMCs and the production of unique structures that can be made only by electron beam processing.

Prior to the Cooperative Research And Development Agreement (CRADA), this technology was relatively unknown and the "best" electron beam curable materials that were available at the time had low performance properties, and were unsuitable for use in the fabrication of most structural composites.

\section{DESCRIPTION}

The purpose of the CRADA was to conduct research and development activities to better understand and utilize the electron beam PMC curing technology. This technology will be used to replace or supplement existing PMC thermal curing processes in Department of Energy (DOE) Defense Programs (DP) projects and American aircraft and aerospace industries. This effort involved Lockheed Martin Energy Systems, Inc./Lockheed Martin Energy Research Corp. (Contractor), Sandia National Laboratories, and ten industrial Participants including four major aircraft and aerospace companies, three advanced materials companies, and three electron beam processing organizations. 
The technical objective of the CRADA was to synthesize and/or modify high performance, electron beam curable materials that meet specific end-use application requirements. There were six tasks in this CRADA including: Electron Beam Materials Development; Electron Beam Database Development; Economic Analysis; Low-Cost Electron Beam Tooling Development; Electron Beam Curing Systems Integration; and Demonstration Articles/Prototype Structures Development.

The Contractor managed, participated and integrated all the tasks, and optimized the project efforts through the coordination, exchange, and dissemination of information to the project Participants. Members of the Contractor team were also the principal inventors on several electron beam related patents and a 1997 R\&D 100 Award winner on "Electron-Beam-Curable Cationic Epoxy Resins."

The Participants in the CRADA were divided into three main areas: Materials Developers; Accelerator Operators; and Manufacturers/Prime Contractors. The Materials Developers included: Applied Poleramics, Inc.; Ciba Geigy Corp.; Sandia National Laboratory; and UCB Chemicals Corp. These organizations developed, formulated, supplied, and tested resin/prepreg systems and photoinitiator chemicals. The Accelerator Operators included: AECL Technologies, Inc.; E-Beam Services, Inc.; and Nicolet Electron Services. These partners provided large amounts of beam time; processed resin/prepreg development material samples and composite parts/structures; and exposed tooling samples. The Manufacturers/Prime Contractors included: Boeing Commercial Airplane Group; Lockheed Aero \& Naval Systems; Lockheed Martin Tactical Aircraft Systems; and Northrup Grumman, B-2 Division. These organizations provided guidance, data, and assistance in economic modeling; initiated and conducted cure monitoring studies; tested materials and components; fabricated demonstration parts; and participated in tooling materials studies and processing studies.

CRADA Accomplishments included:

- Developed a family of rapidly curing, radiation-curable polymer resins for composites and adhesives;

- Received 1997 R\&D 100 Award "Electron-Beam-Curable Cationic Epoxy Resins,"

- Filed four patent applications,

- Granted three commercial licenses,

- Published several technical papers.

- Determined that significant cost savings can be realized using this technology.

- Demonstrated that complex composite parts can be made with inexpensive, light-weight tooling materials;

- Produced unique composite parts that can only be made using this technology,

- Produced many electron beam cured composite parts using several conventional manufacturing methods.

- Conducted radiation stability studies on a large number of inexpensive, lightweight tooling materials. 
Electron beam curing technology dramatically reduces both the processing time and the overall manufacturing costs for these lightweight products. The development of the electron beam curable materials with engineering properties that meet the demanding requirements of highperformance composites makes it possible to build quality products while eliminating requirements for expensive fabrication tools; slow, high-temperature, high-pressure curing cycles; harmful chemical hardeners; and volatile emissions. Electron beam curable cationic epoxy resins are a truly enabling technology for the low-cost fabrication of composite components and the manufacture of unique products that cannot be built any other way.

\section{BENEFITS TO DOE}

Several DOE-DP benefits resulted from the CRADA including:

- Development of high-performance, electron beam curable cationic epoxy resin formulations for use in composites, adhesives, tooling compounds, potting compounds, syntactic foams, etc.

- Elimination of hazardous and carcinogenic hardeners (chemicals) in electron beam curable resin system formulations.

- The production of volatiles is minimized during processing.

- Minimization of the use of harmful and environmentally stressful cleaning solvents.

- Improved resin stability and working life at ambient temperatures;

- No refrigeration required for storing/transporting electron beam curable materials,

- Less waste is generated using this technology.

- Unique products can be manufactured using this technology that cannot be made any other way.

- The curing energy-absorption profile can be controlled, allowing greater design flexibility.

- Curing time is reduced.

- Manufacturing costs for producing composite parts/structures are reduced.

- Incorporation of metallic inserts or temperature sensitive materials into composite parts/structures can be realized.

Although DOE has no near term plans for the design and build of new weapons, should those plans change the electron beam curing process holds a real potential as a part of the next generation weapon. With the ability to cure complex geometric shapes without flaws in short time, the electron beam process would fill several technology gaps and deliver technology advancements to the weapons program. Until the need is identified, future development of electron beam curing will continue through its commercialization efforts with the private sector.

\section{ECONOMIC IMPACT}

The CRADA achieved a major breakthrough for the composites industry by having successfully developed high-performance electron beam curable cationic epoxy resins for use in composites, adhesives, tooling compounds, potting compounds, syntactic foams, etc. UCB Chemicals, the world's largest supplier of radiation-curable polymers, has acquired a license to produce and sell these resins worldwide. 
Industry leaders in the PMC field have recognized the commercial significance of electron beam curable cationic epoxy resins. Research sponsors for the development include the "big three" of the U.S. aerospace industry (Boeing, Lockheed Martin, and Northrop Grumman). All three, along with other companies and the government of the United States, are conducting additional research in the use of electron beam cured composites for diverse applications.

\section{PROJECT STATUS}

This project is completed. However, other work in this technology area is currently on-going with Lockheed Martin and various industrial companies and governmental organizations.

\section{DOE FACILITY POINT(S) OF CONTACT FOR PROJECT INFORMATION:}

CRADA Principal Investigator:

Chris J. Janke

Development Engineer

Oak Ridge National Laboratory

Phone: (423) 574-9247

Fax: (423) 574-8257

Email: jnk@ornl.gov

\section{COMPANY AND POINT(S) OF CONTACT:}
Partner(s):
Contact:
Phone/Fax:
1. Sandia National Laboratory
Dave Wheeler
505-844-6631/505-844-9624
2. AECL Technologies, Inc.
Chris Saunders
204-753-2311/204-753-8802
3. Applied Poleramic, Inc.
Rich Moulton
707-747-6738/707-747-6774
4. Boeing Commercial
Terry Tsuchiyama
206-965-0138/206-965-1440
5. Ciba-Geigy Corporation
Yafim Blaykman
914-785-3104/914-785-3475
6. E-Beam Services, Inc.
Tom Knobel
609-655-7460/609-655-1094
7. Lockheed Martin Tactical Aircraft
Ben Clark
$817-777-4854 / 817-777-4254$
8. Lockheed Martin Aero \& Naval
Alla Oliger
410-682-1000/410-682-1116
9. Nicolet Electron Services
Lewis Parks
619-271-6330/619-271-0957
10. Northrop Grumman, B-2 Div.
Anna Yen
562-942-5392/562-948-0100
11. UCB Chemicals Corporation
Morris Johnson

\section{PROJECT EXAMPLES}

Numerous demonstration parts produced from electron beam curable PMCs have been fabricated during the CRADA. These carbon-fiber, glass-fiber, and polyethylene-fiber-reinforced composites have been manufactured using various composite fabrication processes including hand lay-up, filament winding, resin transfer molding and vacuum assisted resin transfer molding. Parts produced using this technology include: ultra-thick composites cured via X-rays and fabricated by filament winding and resin transfer molding; resin transfer molded domed part made of low density polyethylene material; parts made with multiple fiber materials and cured 
concurrently; I-beam parts cured rapidly on low-cost tooling materials; parts made on low-cost tooling including wax forms and styrofoam blocks; prototype helmets made from low density polyethylene materials; various filament-wound cylinders fabricated on low-cost, light-weight tooling materials including one part composed of an epoxy resin having an extremely high thermal stability; and several sandwich composite parts fabricated with various honeycomb and foam core materials.

\section{TECHNOLOGY COMMERCIALIZATION}

Electron-Beam-Curable Cationic Epoxy Resins invented (patents pending) as a result of this CRADA are currently being commercialized and sold by two licensees of the technology. These licensees include: Applied Poleramic, Inc., Benicia, CA; and UCB Chemicals Corporation, Smyrna, GA. Sales of these materials have been initiated.

Additionally, Lockheed Martin is pursuing implementation of this technology in various areas including: military aviation; commercial aviation; space exploration; manned spacecraft; energy applications; transportation applications; infrastructure; sporting goods; electronics; and various military applications. 


\section{Distribution List:}

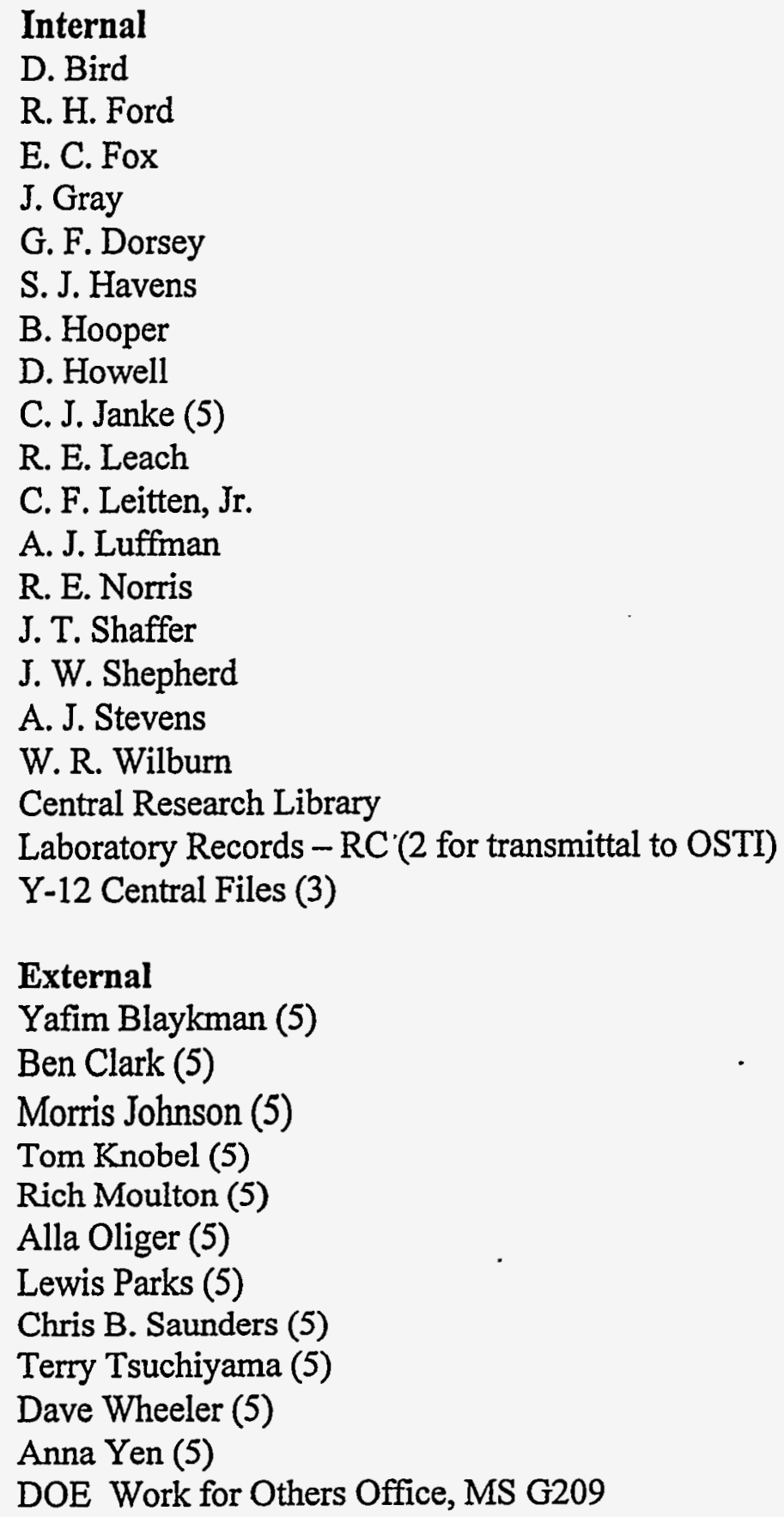

R. E. Norris

J. T. Shaffer

J. W. Shepherd

A. J. Stevens

W. R. Wilburn

Central Research Library

Laboratory Records - RC'(2 for transmittal to OSTI)

Y-12 Central Files (3)

\section{External}

Yafim Blaykman (5)

Ben Clark (5)

Morris Johnson (5)

Tom Knobel (5)

Rich Moulton (5)

Alla Oliger (5)

Lewis Parks (5)

Chris B. Saunders (5)

Terry Tsuchiyama (5)

Dave Wheeler (5)

Anna Yen (5)

DOE Work for Others Office, MS G209 